\title{
REVITALISASI SEKAA MANYI (KELOMPOK PEMANEN PADI) UNTUK MENINGKATKAN PENDAPATAN WANITA TANI DI DESA REJASA KECAMATAN PENEBEL KABUPATEN TABANAN
}

\author{
N.N. Soniari ${ }^{1}$, N.W.Siti ${ }^{2}$, N.K. Seminari ${ }^{3}$ dan N.M. Witariadi ${ }^{4}$
}

\begin{abstract}
ABSTRAK
Subak Rejasa adalah salah satu subak yang eksistensinya masih kuat di daerah lumbung padi di kabupaten Tabanan, dengan system pengairan yang terorganisir baik. Eksisnya subak sangat mendukung keberhasilan pertanian, khususnya persawahan, karena tata kelola air yang adil dan merata,serta penetapan waktu dan pola tanam yang teratur. Subak membawahi beberapa sekaa (kelompok) seperti sekaa Numbeg, sekaa Jelinjingan, sekaa Sambang, sekaa Nandur, sekaa Mejukut, sekaa Manyi, dan sekaa Bleseng. Namun seiring dengan kemajuan teknologi dan adanya alih fungsi lahan menyebabkan keberadaan sekaa-sekaa tersebut tergerus oleh zaman.Salah satu sekaa yang sulit ditemukan sekarang adalah sekaa Manyi (kelompok pemanen tradisional Bali). Metode yang ditempuh dalam program revitalisasi sekaa Manyi ini adalah menentukan kelompok sasaran yang sungguh-sungguh berminat menjadi sekaa, pembuatan AD dan ART sekaa, melakukan pelatihan dan penyuluhan dengan sentuhan teknologi tepat guna yang inovatif, serta melengkapi sarana berupa mesin perontok ( power trasher). Revitalisasi sekaa Manyi bertujuan membangkitkan, membentuk dan memperkuat kembali kelompok pemanen ini untuk memenuhi kebutuhan saat musim panen padi. Terjadi efisiensi di bidang penanganan hasil panen hampir $50 \%$.dibandingkan menggunakan tenaga pemanen dari luar.
\end{abstract}

Kata kunci : revitalisasi, kelompok pemanen padi, peningkatan, pendapatan

\begin{abstract}
Subak Rejasa is one subak whose existence is still strong in the area of rice barns in Tabanan regency, with a well-organized irrigation system. The existence of subak strongly supports the success of agriculture, especially rice fields, because of fair and equitable water governance, as well as setting time and regular cropping patterns. Subak is in charge of several sekaa (groups) such as Seka Numbeg, Sekaa Jelinjingan, Sekaa Sambang, Sekaa Nandur, Sekaa Mejukut, Sekaa Manyi, and Sekaa Bleseng. But along with technological advances and the transfer of land functions, the existence of these sekaa-sekaa was eroded by the times. One of the groups that is hard to find now is Sekaa Manyi (a traditional Balinese harvester group). The method adopted in the Sekaa Manyi revitalization program is to determine the target groups who are truly interested in becoming sekaa, the creation of sekaa statutes and bylaws, conducting training and counseling with innovative touches of appropriate technology, as well as completing facilities such as power trasher. Sekaa Manyi's revitalization aims to revive, shape and reinforce this harvesting group to meet the needs during the rice harvest season. Efficiency occurs in the field of handling yields of almost $50 \%$. Compared to using harvesters from outside.
\end{abstract}

Keywords: revitalization, group of rice harvesters, enhancement, income

\footnotetext{
${ }^{1}$ Dosen Program Studi Agroekoteknologi Fakultas Pertanian Universitas Udayana,nsoniari@unud.ac.id

${ }^{2}$ Dosen Program Studi Peternakan Fakultas Peternakan Universitas Udayana,wsiti@unud.ac.id

${ }^{3}$ Dosen Program Studi Manajemen Fakultas Ekonomi Universitas Udayana, kseminari@unud.ac.id

${ }^{4}$ Dosen Program Studi Peternakan Fakultas Peternakan Universitas Udayana, mwitariadi@unud.ac.id
} 


\section{PENDAHULUAN}

Sekaa manyi adalah kelompok pemanen padi tradisional di Bali, yang bernaung di bawah organisasi subak dan dibentuk berdasarkan kebersamaan dan gotong royong. Selain sekaa manyi subak juga membawahi sekaa - sekaa (kelompok) seperti (1) Sekaa Numbeg,yaitu sebuah kelompok yang mengatur hal pengolahan tanah, (2) Sekaa Jelinjingan, kelompok yang bertugas untuk mengatur pengolahan air.(3) Sekaa Sambang, yaitu kelompok yg memiliki tugas dalam hal pengawasan air dari pencurian, penangkap atau penghalau binatang perusak tanaman seperti burung maupun tikus.(4). Sekaa Memulih/Nandur, yaitu kelompok yang bertugas dalam hal penanaman bibit padi, (5). Sekaa Mejukut yaitu kelompok yang bertugas menyiangi padi. (6). Sekaa Bleseng yaitu kelompok yang memiliki tugas mengangkut ikatan padi yang telah diketam dari sawah ke lumbung. Setiap sekaa memiliki peran dan fungsi masing-masing dan tidak saling tumpang tindih sehingga kerjasama dan gotong-royong menjadi karakter utama dalam sistem kemasyarakatan ini (Marteda, 2018).

Fenomena yang terjadi sekarang adalah petani semakin sedikit jumlahnya selaras dengan penurunan luas lahan yang dapat diolah, di samping itu generasi penerus enggan menggeluti profesi ini. Hal ini disebabkan oleh banyak factor antara lain : alih fungsi lahan dari lahan persawahan menjadi pemukiman dan fungsi lainnya mengakibatkan lahan pertanian terus berkurang, terganggunya system subak, sehingga banyak lahan sawah yang tidak teraliri air irigasi. Biaya proses produksi menjadi meningkat, karena petani mengandalkan buruh tani dari luar untuk pengolahan tanah, penanaman hingga panen (Rosyadi,2016). Jika hal ini tidak mendapat perhatian dari pemerintah untuk membangun,memotivasi dan menguatkan kembali komponen-komponen penting masyarakat dalam pertanian khususnya persawahan, jelas akan terjadi impor beras besarbesaran.

Berdasarkan fakta yang kini terjadi, maka sangat penting untuk menumbuhkan kembali semangat pertanian yang telah memudar dengan merevitalisasi sekaa-sekaa(kelompok) di masyarakat yang berhubungan dengan pertanian. Revitalisasi sekaa manyi di subak rejasa merupakan suatu usaha untuk melepaskan ketergantungan petani lokal terhadap buruh tani dari luar daerah dan mengurangi beban biaya produksi, serta melestarikan budaya leluhur Nusantara.

\section{METODA PELAKSANAAN}

Pengabdian masyarakat revitalisasi sekaa manyi untuk meningkatkan pendapatan wanita tani di Desa Rejasa diarahkan untuk membentuk wanita tani menjadi lembaga yang memiliki wawasan kewirausahaan menuju wirausaha mandiri. Menurut Sardiana, dkk (2015) wirausaha mandiri dicirikan oleh : (1) menguasai kemampuan manajerial usaha; (2) menghasilkan komoditas usaha berupa barang dan jasa yang unik dan inovatif berbasis pengembangan Iptek (ilmu pengetahuan dan teknologi), dan (3) telah mampu mengkases permodalan ke berbagai sumber permodalan komersial.

Program beras sehat pemda Tabanan merangkul masyarakat petani melalui subak-subak yang ada di Tabanan dengan bantuan saprodi, SOP dan teknik budidaya hingga pemasaran. Tim pelaksana melakukan pendampingan dalam proses pengolahan tanah hingga panen . Khusus untuk menangani panen padi, Tim membentuk sekaa Manyi yang terdiri dari petani pemilik dan penyakap sawah di subak rejasa. Untuk memotivasi dan meringankan petani dalam proses pemanenan, tim menyumbangkan 1 unit mesin perontok (power thresher) (Gambar 1.). Keanggotaan,managemen sekaa,serta penggunaan alat ini diatur dalam AD/ART sekaa Manyi. Evaluasi kinerja sekaa, efisiensi ,serta keuntungan yang diperoleh dilakukan pada akhir program. 


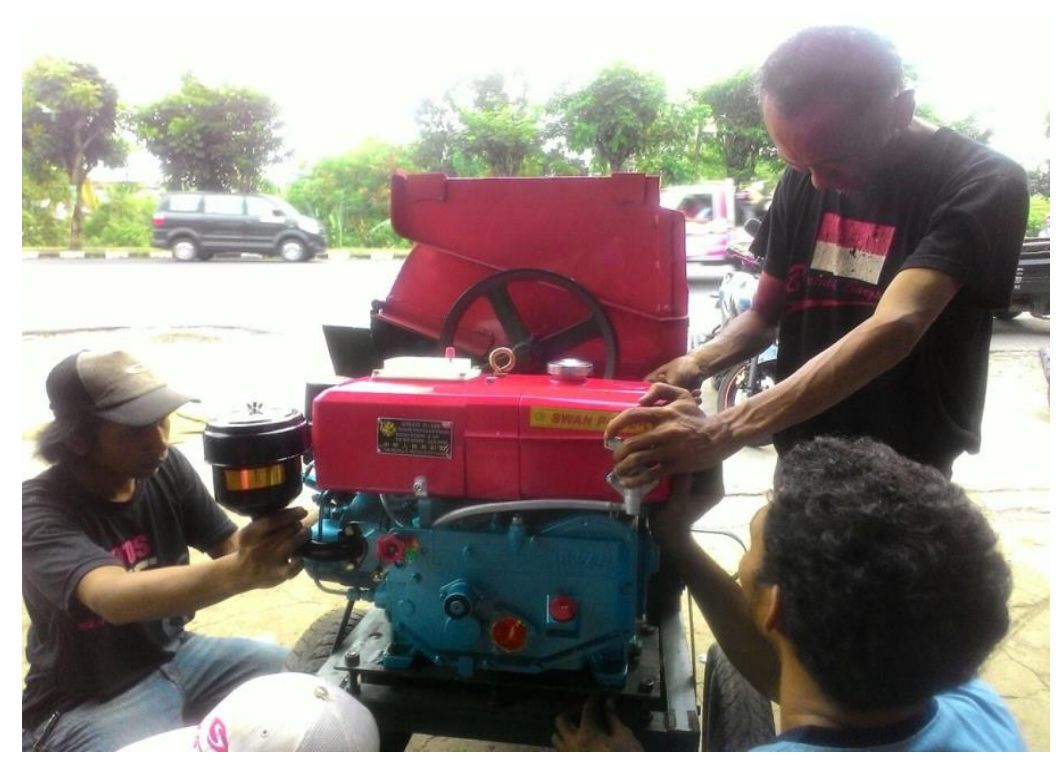

Gambar 3.1. Alat panen padi yang digerakan mesin

\section{HASIL DAN PEMBAHASAN}

Rangsangan untuk mengurangi ketergantungan petani terhadap tenaga pemanen dari luar dengan membentuk sekaa Manyi dan melengkapi sarana yang diperlukan dalam proses pemanenan padi. Tim berusaha menyumbangkan mesin perontok (power trasher) 1 unit, untuk mengawali usaha menghidupkan kegiatan sekaa Manyi. Awal pembentukan sekaa diikuti oleh 25 orang petani pemilik dan penyakap sebagai anggota, yang sebagian besar merupakan anggota subak Rejasa. Tim PKW berkoordinasi dengan sekaa dan memfasilitasi pembuatan AD/ART untuk mengatur keanggotaan, hak,dan kewajiban, serta aturan lain untuk menjamin keberlangsungan kelompok ini .

Sumbangan mesin perontok merupakan sentuhan teknologi tepat guna bagi petani dalam proses pemanenan padi. Anggota sekaa semangat karena sangat dimudahkan oleh penggunaan mesin perontok ini. Bila dibandingkan dengan proses perontokan padi secara tradisional maka ada efisiensi waktu yang sangat signifikan yakni untuk proses perontokan dengan luasan 25 are yang biasanya dikerjakan selama $6-7$ jam secara manual melibatkan tenaga 8 orang, bisa dihemat menjadi 2 jam dengan mesin perontok. Disamping efisiensi waktu dengan mesin perontok, kehilangan gabah dapat diminimalisir. Rata-rata hasil gabah $13 \mathrm{kwintal} / 25$ are. Khusus untuk anggota sekaa ongkos perontokan hingga gabah bersih adalah Rp70.000,-/kwintal dan bila di luar anggota ongkosnya Rp.80.000,- hingga Rp100.000,-/kwintal gabah bersih tergantung jarak lokasi dari pinggir jalan. Upah harian tiap anggota adalah Rp.100.000,-dan pengerjaan panen dengan mesin perontok jauh lebih santai (nara sumber : anggota sekaa manyi).

Pergiliran tugas diatur dalam AD/ART serta keputusan rapat anggota sekaa dengan asas pemerataan dan keadilan. Nama kelompok, ketentuan keanggotaan, hak, kewajiban dan sanksi juga secara rinci telah dituangkan dalam AD/ART, sehingga keberadaan, aktivitas dan kelangsungan sekaa menjadi jelas bagi setiap anggota. Sekaa dibentuk atas dasar kebersamaan dan gotong royong serta bernaung di bawah organisasi Subak. Maksud pembentukan Sekaa Manyi ini adalah untuk melestarikan budaya di bidang pertanian dan meningkatkan efisiensi biaya proses produksi gabah. Tujuan pembentukan sekaa manyi adalah ( 1).Pemberdayaan masyarakat petani dan kemandirian penanganan hasil panen. (2).Meningkatkan pendapatan kelompok petani melalui aktivitas sekaa dalam mengerjakan ataupun menyewakan mesin perontok (power trasher). (3). Mewujudkan kelembagaan tradisional yang memberikan pelayanan terhadap anggota kelompok 
maupun kelompok petani lainnya (khususnya panen padi), (4) Mendorong berkembangnya usaha mikro sektor informal, (5) Menciptakan kesempatan berusaha dan membuka lapangan kerja.

Modal awal Sekaa Manyi berasal dari bantuan program IbW (Ipteks bagi Wilayah) Universitas Udayana tahun 2016 berupa 1 unit mesin perontok padi (trasher) dan hingga kini sekaa telah berkembang serta telah memiliki kekayaan berupa uang dari hasil penyewaan mesin baik dari anggota maupun non anggota, yang selanjutnya akan digunakan untuk pengembangan usaha sekaa. Modal lain yang tidak kalah pentingnya adalah semangat kebersamaan dari anggota sekaa.

\section{KESIMPULAN DAN SARAN}

1) Melalui revitalisasi sekaa manyi kelembagaan tradisional dalam penanganan hasil panen padi kembali bangkit mengantisipasi ketergantungan akan tenaga pemanen dari luar Bali.

2) Tumbuhnya rasa kebersamaan dan gotong royong di masyarakat atas kebutuhan yang sama.

3) Penggunaan mesin perontok memberikan efisiensi biaya, tenaga dan waktu panen.

4) Sentuhan teknologi tepat guna sangat bermanfaat untuk memberdayakan masyarakat petani dan mendukung kelestarian pertanian.

\section{UCAPAN TERIMAKASIH}

Ucapan terimakasih kami sampaikan kepada Direktorat Riset dan Pengabdian Masyarakat Kemenristek Dikti atas dana yang telah diberikan sehingga program pengabdian masyarakat ini dapat berjalan dengan baik.

\section{DAFTAR PUSTAKA}

[Bappeda] Badan Perencanaan Pembangunan Kabupaten Tabanan, 2011. Rencana Pembangunan Jangka Menengah Kabupaten Tabanan.

[BPS] Badan Pusat Statistik . 2011. Kabupaten Tabanan dalam Angka. Badan Pusat Statistik kabupaten Tabanan.

Sardiana, I.K., B.R.T. Putri, I.G. Suranjaya, N.L.R. Purnawan. 2015. Pengembangan Kewirausahaan Di Universitas Udayana. Majalah Aplikasi Ipteks Ngayah : Vol. 6, No. 1, pp. 91-101.

https://elinkbalinews.com/read/2016/05/13/201605130001/Beras-Sehat-dan-Perlindungan-Petani.html. Diakses tanggal 20 Juni 2018

https://www.kompasiana.com/gede.marteda/5a4f2282caf7db195862a6c2/subak-pancasila-danpembangunan-zaman-now./2018 Diakses tanggal 24 Juni 2018 